\title{
Clinical profile and outcome of newborns who underwent double volume exchange transfusion in the neonatal intensive care unit at B.P. Koirala Institute of Health Sciences, Nepal
}

\author{
*Piush Kanodia ${ }^{1}$, Sunil Kumar Yadav ${ }^{1}$, Nisha Keshary Bhatta ${ }^{1}$, Rupa Rajbhandari Singh ${ }^{1}$, Shankar \\ Prasad Yadav ${ }^{1}$
}

Sri Lanka Journal of Child Health, 2016; 45(4): 267-270

\begin{abstract}
Introduction: About 50\% term and $80 \%$ preterm babies develop neonatal jaundice. Treatment to prevent bilirubin encephalopathy consists of phototherapy or exchange transfusion (ET). ET is not risk free, and mortality rates vary from 0.5 to $3.3 \%$.
\end{abstract}

Objective: To report our observations on efficacy, adverse events and factors contributing to mortality related with ET performed for the treatment of neonatal hyperbilirubinemia at a tertiary-care centre.

Method: This retrospective study was conducted at the neonatology division of B.P. Koirala Institute of Health Sciences, Nepal. All neonates who required ET for jaundice from January 2013 to December 2014 were included.

Results: Sixty four neonates underwent double volume ET. Predominant causes of hyperbilirubinaemia were ABO incompatibility (32.8\%), Rh incompatibility (17.2\%) and idiopathic $(20.3 \%)$. There was a mean reduction in serum bilirubin levels to $13.1 \pm 3.82 \mathrm{mg} / \mathrm{dl}$ in the post-ET and $14.63 \pm 3.16 \mathrm{mg} / \mathrm{dl}$ in the 6 hour post-ET period. The common adverse events were hypocalcaemia in $50 \%$ and thrombocytopenia in $35.9 \%$ of neonates. Other events such as hypoglycaemia $(17.2 \%)$, apnoea $(18.8 \%)$ and mortality (3.1\%) occurred following ET.

Conclusions: ABO incompatibility was the commonest cause for ET. Most of the complications were transient. Mortality rate was $3.1 \%$ in this study.

${ }^{1}$ Department of Paediatrics, Neonatology Division,

B. P. Koirala Institute of Health Sciences, Nepal

*Correspondence: piushkanodia@yahoo.com

(Received on 18 January 2016: Accepted after revision on 17 March 2016)

The authors declare that there are no conflicts of interest

Personal funding was used for this project.

Open Access Article published under the Creative

Commons Attribution CC-BY (CC) (†)
DOI: http://dx.doi.org/10.4038/sljch.v45i4.8061

(Key words: Exchange transfusion, neonatal hyperbilirubinemia, adverse events)

\section{Introduction}

Neonatal hyperbilirubinemia is a common cause of admission to the neonatal intensive care unit $(\mathrm{NICU})^{1}$. About $50 \%$ of term and $80 \%$ of preterm babies develop jaundice during the neonatal period ${ }^{2}$ but only $0.02-0.16 \%$ develop extreme hyperbilirubinaemia ${ }^{3}$. Breast milk jaundice, ABO incompatibility, $\mathrm{Rh}$ incompatibility, Glucose-6phosphate deficiency (G-6-PD), East Asian ethnicity and cephalhaematoma are conditions associated with severe jaundice ${ }^{4}$. The serum bilirubin level varies with birth weight, gestational age, chronological age and internal milieu of the body. When total serum bilirubin level exceeds a critical limit, it crosses the blood brain barrier and results in bilirubin encephalopathy ${ }^{5}$. Treatment is always given to prevent bilirubin encephalopathy by phototherapy or exchange transfusion (ET) ${ }^{6}$. Although ET is considered to be a safe procedure, it is not risk free, and mortality rates vary from 0.5 to $3.3 \% \%^{4,7,9}$. Recently, the number of ETs has been significantly reduced due to the availability of highly effective double surface and LED phototherapy and intravenous immunoglobulin $\mathrm{G}$ (IVIg) in prevention of isoimmunization / blood group incompatibility ${ }^{10}$. ET is sufficient to minimize brain damage, despite the adverse event $^{11}$.

\section{Objectives}

To report our observations on efficacy, adverse events and factors contributing to mortality related with ET performed for the treatment of neonatal hyperbilirubinemia at a tertiary-care centre.

\section{Method}

This retrospective study was conducted at the Neonatology Division of B.P. Koirala Institute of Health Sciences (BPKIHS), Nepal. All neonates who required ET from January 2013 to December 2014 were included. The criteria for ET for the management of hyperbilirubinaemia were followed as per American Academy of Paediatrics 2004 guidelines ${ }^{12}$. Cases of ET for conditions other than jaundice were excluded from the study. The study 
was approved by the Institute Ethical Review Board. Detailed baseline characteristics and clinical findings were recorded in a pre-designed proforma. Investigations such as blood glucose, total and indirect serum bilirubin (SB), ionized calcium, haematocrit, haemoglobin, total and differential leucocyte counts, platelet counts and peripheral blood smear, reticulocyte count and direct Coombs test were performed. ABO and Rh blood grouping of both baby and mother were done. Rh disease was defined as jaundice in Rh positive newborns born to Rh negative mothers with elevated antibody titre to the $\mathrm{Rh}$ antigen and evidence of haemolysis. $\mathrm{ABO}$ disease was attributed as a cause of jaundice in newborns with positive direct Coombs test against the $\mathrm{A}$ or $\mathrm{B}$ antigens from type $\mathrm{O}$ mothers. Infant's blood volume was taken as $80 \mathrm{ml} / \mathrm{kg}$ and so $160 \mathrm{ml} / \mathrm{kg}$ of blood was required for ET, which replaces $87 \%$ of the infant's blood volume with new blood. Exchange was done under a servocontrolled radiant warmer with monitoring of vital parameters. Exchanges were done by the push-pull technique with stored whole blood of less than 5 days duration. Umbilical catheter was inserted as far as required to permit free blood exchange. Blood was removed in aliquots tolerated by the infant, which was $5 \mathrm{ml}$ for infants $<1,500 \mathrm{~g}, 10 \mathrm{ml}$ for infants 1,500 to $2,500 \mathrm{~g}, 15 \mathrm{ml}$ for infants 2,500 to $3,500 \mathrm{~g}$, and $20 \mathrm{ml}$ for infants $>3,500 \mathrm{~g}$. If jaundice was the only problem and the baby was active and taking feeds adequately, the baby was considered as a healthy newborn, as opposed to sick neonates who had ongoing illnesses such as birth asphyxia, meconium aspiration syndrome or respiratory distress syndrome that required treatment prior to or at the same time as ET. The adverse events which occurred during and within 3 days of the procedure were observed and managed accordingly. The catheter was removed after the procedure. In sick neonates, supportive treatment in the form of intravenous fluids, oxygen inhalation and empiric antibiotics (ampicillin + amikacin) were given. The antibiotics were changed after culture report as per antimicrobial sensitivity pattern. Biochemical abnormalities such as hypoglycaemia and hypocalcaemia were corrected before doing the ET. However, no intermittent infusions of calcium were given during the procedure as per our NICU protocol. IVIg was not used in any neonate with $\mathrm{Rh}$ isoimmunization because of high cost and non-affordability by the parents. Data were analysed using the SPSS version 20.0. Chi-square and Fisher Exact tests were applied to compare the data of proportions and Student's $t$-test was used for quantitative variables. A 'p' value less than 0.05 was considered as statistically significant.

\section{Results}

ET was performed in 64 neonates. Basic characteristics of the study subjects are shown in Table 1.

Table 1: Basic characteristics of study subjects

\begin{tabular}{|c|c|c|c|c|}
\hline \multirow{2}{*}{\multicolumn{2}{|c|}{ Characteristics }} & \multicolumn{2}{|c|}{ Gestational age } & \multirow[t]{2}{*}{ P value } \\
\hline & & $\begin{array}{c}37 \text { weeks or }> \\
(n=48)\end{array}$ & $<37$ weeks $(n=16)$ & \\
\hline \multicolumn{2}{|c|}{ Body weight $(\mathrm{Kg})($ mean $\pm \mathrm{SD})$} & $3.01 \pm 0.47$ & $1.587 \pm 0.47$ & $<.001$ \\
\hline \multicolumn{2}{|c|}{ Age at ET (days) (mean \pm SD) } & $3.67 \pm 2.24$ & $4.25 \pm 1.39$ & 0.226 \\
\hline \multirow[t]{2}{*}{ Gender } & Male & $31(64.6 \%)$ & $08(50.0 \%)$ & \multirow[t]{2}{*}{0.300} \\
\hline & Female & $17(35.4 \%)$ & $08(50.0 \%)$ & \\
\hline \multirow[t]{2}{*}{ Race } & Mongolian & $24(50.0 \%)$ & $08(50.0 \%)$ & \multirow[t]{2}{*}{1.000} \\
\hline & Non-Mongolian & $24(50.0 \%)$ & $08(50.0 \%)$ & \\
\hline \multirow[t]{2}{*}{ Place of delivery } & Inborn & $27(56.2 \%)$ & $05(31.2 \%)$ & \multirow[t]{2}{*}{0.083} \\
\hline & Outborn & $21(43.8 \%)$ & $11(68.8 \%)$ & \\
\hline \multirow[t]{2}{*}{ Mode of delivery } & SVD & $30(62.5 \%)$ & $14(87.5 \%)$ & \multirow[t]{2}{*}{0.62} \\
\hline & LSCS & $18(37.5 \%)$ & $02(12.5 \%)$ & \\
\hline
\end{tabular}

SVD: Spontaneous vaginal delivery; LSCS: Lower segment caesarean section; SD: Standard deviation

There were 16 preterm and 48 term neonates. Term neonates had significantly higher mean body weight than preterm neonates $(p<0.001)$. Other parameters such as age at exchange transfusion, gender, race and place of delivery were comparable between preterm and term neonates.

Causes of hyperbilirubinaemia included ABO incompatibility $(32.8 \%), \quad \mathrm{Rh}$ incompatibility
(17.2\%) G6PD deficiency (1.6\%) and idiopathic $(20.3 \%)$. ET was done once in $62(96.9 \%)$ and twice in $2(3.1 \%)$. Mean serum bilirubin levels were $13.1 \pm 3.82 \mathrm{mg} / \mathrm{dl}$ post ET and $14.63 \pm 3.16$ $\mathrm{mg} / \mathrm{dl} 6$ hour post-ET period. The mean serum bilirubin levels in study subjects are presented in Table 2. 
Table 2: Serum bilirubin levels (mg/dl) in study subjects (mean \pm SD)

\begin{tabular}{|l|c|c|c|}
\hline \multirow{2}{*}{ Group } & \multicolumn{2}{c|}{ Gestational age } & \multirow{2}{*}{ P value } \\
\cline { 2 - 3 } & $>\mathbf{3 7}$ weeks $(n=48)$ & $<\mathbf{3 7}$ weeks $(n=16)$ & \\
\hline Pre Exchange Transfusion & $24.12 \pm 4.01$ & $22.55 \pm 2.45$ & 0.70 \\
\hline Post Exchange Transfusion & $13.51 \pm 3.93$ & $11.84 \pm 3.26$ & 0.102 \\
\hline 6 hours post Exchange Transfusion & $14.91 \pm 3.36$ & $13.8 \pm 2.35$ & 0.154 \\
\hline
\end{tabular}

Bilirubin levels declined in post-ET and 6 hour post-ET period in comparison to pre-ET values. The term neonates had higher levels of mean SB at all stages (pre-ET, post-ET \& 6 hour post-ET) when compared with preterm but this was not statistically significant. The neonates had more than one adverse event and thus 70 adverse events occurred in 64 babies during three days following ET, as shown in Table 3.

Table 3: Adverse events following 3 days of ET

\begin{tabular}{|c|c|}
\hline Adverse event & Complication \\
\hline Hypocalcaemia & $32(50.0 \%)$ \\
\hline Thrombocytopenia & $23(35.9 \%)$ \\
\hline Apnoea & $12(18.8 \%)$ \\
\hline Hypoglycaemia & $11(17.2 \%)$ \\
\hline Death & $02(03.1 \%)$ \\
\hline Total & 70 \\
\hline
\end{tabular}

\section{Discussion}

Prevention of bilirubin encephalopathy is essential and ET is an emergency procedure. In the present study the mean age for ET was 3.7 days and 4.3 days in term and preterm newborns respectively. At BPKIHS newborns come from far off and there are late referrals from peripheral health centres. The common causes of hyperbilirubinaemia were $\mathrm{ABO}$ incompatibility (33\%), idiopathic (20\%) and $\mathrm{Rh}$ incompatibility (17\%). Steiner et al. ${ }^{10}$ and Behjata et $a l .{ }^{11}$ found $\mathrm{ABO}$ incompatibility in $28 \%$ and $52 \%$ respectively. However, Behjata et al. ${ }^{11}$ also reported $\mathrm{Rh}$ incompatibility in $12 \%$. Idiopathic aetiology was the second common cause because we are unable to find any attributable cause in neonates with indirect hyperbilirubinaemia. In different studies idiopathic aetiology varied from $13.9 \%$ to $36.4 \%{ }^{13-15}$. In our study ET was performed once in $97 \%$ of neonates and more than once in 3\% of cases. Multiple ET was also reported by other workers ${ }^{14,16}$. The mean SB level in post ET $(13.1 \pm 3.82)$ and 6 hour post-ET $(14.63 \pm 3.16)$ samples showed a decrease from the pre-ET value but this was not statistically significant. Further, there was a rise in the SB level in the 6 hour postET period despite continued phototherapy. Thus, ET removes about $60 \%$ of bilirubin from plasma, resulting in a clearance of 30 to $40 \%$ of bilirubin ${ }^{17}$. Following 3 days of ET, hypocalcaemia (50\%) and thrombocytopenia $(35.9 \%)$ were the major adverse events. In our study the high incidence of hypocalcaemia was because we did not use prophylactic calcium during the procedure unless it became symptomatic. Whilst $0.5-1.0 \mathrm{ml}$ of $10 \%$ intravenous calcium gluconate, given after each $100 \mathrm{ml}$ of exchange blood, may reduce incidence of hypocalcemia $^{18}$, its use is controversial. Thrombocytopenia (36\%) was another major adverse event. Besides ET, phototherapy can also cause thrombocytopenia. The other events were hypoglycaemia, respiratory distress, apnoea and cardio-respiratory arrest posing additional problems, which require close monitoring during procedure. Two neonates (3\%) died within 24 hours of ET in contrast with other studies which have low mortality rates $(0.5-2.8 \%)^{19,20}$. Newborns undergoing ET need close monitoring and prompt treatment for adverse events.

\section{Conclusions}

In our study $\mathrm{ABO}$ incompatibility was the commonest identified cause of ET. Adverse events remain common after ET. Most complications were transient. Mortality rate was $3 \%$ in this study.

\section{References}

1. Maisels MJ, Kring E. Length of stay, jaundice, and hospital readmission. Pediatrics 1998; 101(6):995-8. http://dx.doi.org/10.1542/peds.101.6.995

2. Jardine LA, Woodgate P. Neonatal jaundice. American Family Physician 2012; 85(8):824-5.

3. Bhutani VK, Johnson LH, Keren R. Diagnosis and management of hyperbilirubinaemia in the term neonate: for a safer first week. Pediatric Clinics of North America 2004; 51:843-61. http://dx.doi.org/10.1016/j.pcl.2004.03.01 1

PMid: 15275978

4. Ip S, Chung M, Kulig J, O’Brien R, Sege $\mathrm{R}$, Glicken $\mathrm{S}$ et al. An evidence-based review of important issues concerning neonatal hyperbilirubinaemia. Pediatrics 2004; 114(1): 130-53.

http://dx.doi.org/10.1542/peds.114.1.e130

5. Brown AK, Damus K, Kim $\mathrm{MH}$ et al. Factors relating to readmission of term and near-term neonates in the first two weeks of life. Early Discharge Survey Group of the Health Professional 
Advisory Board of the Greater New York Chapter of the March of Dimes. Journal of Perinatal Medicine 1999; 27(4):263-75. http://dx.doi.org/10.1515/JPM.1999.037 PMid: 10560077

6. Smitherman H, Stark AR, Bhutani VK. Early recognition of neonatal hyperbilirubinaemia and its emergent management. Seminars in Fetal and Neonatal Medicine 2006; 11(3): 214-24. http://dx.doi.org/10.1016/j.siny.2006.02.0 02

PMid: 16603425

7. Bowman J. The management of haemolytic disease in the fetus and newborn. Seminars in Perinatology 1997; 21(1): 39-44.

http://dx.doi.org/10.1016/S01460005(97)8 0018-3

8. Philip AG. The rise and fall of exchange transfusion. Neo Reviews 2003; 4: 169-74. http://dx.doi.org/10.1542/neo.4-7-e169

9. Boggs TR Jr, Westphal MC Jr. Mortality of exchange transfusion. Pediatrics 1960; 26: $745-55$.

10. Steiner LA, Bizzarro MJ, Ehrenkranz RA, Gallagher PG. A decline in the frequency of neonatal exchange transfusions and its effect on exchange related morbidity and mortality. Pediatrics 2007; 120(1):27- 32. http://dx.doi.org/10.1542/peds.2006-2910 PMid: 17606558

11. Behjata S, Sagheb S, Aryasepehr S, Yaghmai B. Adverse events associated with neonatal exchange transfusion for hyperbilirubinaemia. Indian Journal of Pediatrics 2009; 76:83-5. http://dx.doi.org/10.1007/s12098-009-

0033-1

PMid: 19391007

12. American Academy of Pediatrics Practice Guidelines. Subcommittee on hyperbilirubinaemia. Management of hyperbilirubinaemia in the newborn infant 35 weeks or more of gestation. Pediatrics 2004; 114:297-316. http://dx.doi.org/10.1542/peds.114.1.297 PMid: 15231951
13. Davutoğlu M, Garipardıç M, Güler E et al. The etiology of severe neonatal hyperbilirubinemia and complications of exchange transfusion. Turkish Journal of Pediatrics 2010; 52: 163-6.

PMid: 20560252

14. Bhat AW, Churoo BA, Iqbal $\mathrm{Q}$ et al. Complication of exchange transfusion at a tertiary care hospital. Current Pediatric Research 2011; 15(2):97-9.

15. Sakha SH, Gharehbaghi MM. Exchange transfusion in severe hyperbilirubinemia: an experience in northwest Iran. Turkish Journal of Pediatrics 2010; 52:367-71.

16. Badiee Z. Exchange transfusion in neonatal hyperbilirubinaemia: experience in Isfahan, Iran. Singapore Medical Journal 2007; 48(5):421-3.

PMid: 17453099

17. Maissels MJ. Neonatal hyperbilirubinemia. In: Care of the highrisk neonate. 5th edition. W.B. Sounders. Philadelphia. 2001. pp 363-64. http://dx.doi.org/10.1016/B978-0-72167729-3.50017-2

18. Nelson N, Finnström O. Blood exchange transfusions in newborns, the effect on serum ionized calcium. Early Human Development 1988; 18(2- 3):157-64.

19. Patra K, Storfer-Isser A, Siner B et al. Adverse events associated with neonatal exchange transfusion in the 1990s. Journal of Pediatrics 2004; 144:626-31. http://dx.doi.org/10.1016/j.jpeds.2004.01. 054

PMid: 15126997

20. Choudhury HR, Hasan MA, Yasmin F. Outcome of neonatal hyperbilirubinemia in a tertiary care hospital in Bangladesh. Malays Journal of Medical Science 2010; 17:40-44. 